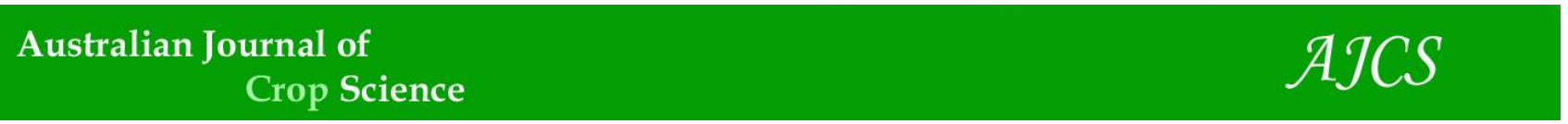

AJCS 14(09):1525-1532 (2020)

ISSN:1835-2707

doi: 10.21475/ajcs.20.14.09.p2783

\title{
Nutritional composition of a selected white food-grade waxy sorghum variety grown in Mediterranean environment
}

\author{
Paola Pontieri ${ }^{1^{*}}$, Jacopo Troisi ${ }^{2}$, Roberta Romano ${ }^{3}$, Graziano Pizzolante ${ }^{4}$, Scott R. Bean ${ }^{5}$, Michael Tilley ${ }^{5}$, \\ Mario Motto ${ }^{6}$, Mariarosaria Aletta ${ }^{7}$, Fabio Del Giudice ${ }^{8}$, Mario Sicardi ${ }^{9}$, Pietro Alifano ${ }^{10}$, Luigi Del Giudice ${ }^{1}$ \\ ${ }^{1}$ Istituto di Bioscienze e BioRisorse-UOS Portici-CNR c/o Dipartimento di Biologia, Sezione di Igiene, Napoli 80134, \\ Italy \\ ${ }^{2}$ Theoreosrl - Spin off of the University of Salerno - Via degli ulivi, 3 Montecorvino Pugliano (SA) Italy \\ ${ }^{3}$ Dipartimento di Ingegneria Civile, Chimica, Ambientale e dei Materiali (DICAM), Università di Bologna 40131, Italy \\ ${ }^{4}$ ZooPlantLab, Dipartimento di Biotecnologie e Bioscienze, Università di Milano-Bicocca, 20126 Milano, Italy \\ ${ }^{5}$ USDA-ARS, CGAHR, Manhattan, KS 66502, USA \\ ${ }^{6}$ Fondazione per le Nuove Tecnologie per la Vita, Bergamo, Italy \\ ${ }^{7}$ DCSRSI SPR BIBLIOTECA - Napoli 80131, Italy \\ ${ }^{8}$ Bioteam Laboratory. via Girolamo Santacroce. Napoli 80129, Italy \\ ${ }^{9}$ Dipartimento di Scienze Economiche e Statistiche - Via Cinthia n ${ }^{\circ} 45$ - Monte S.Angelo, Università di Napoli Federico \\ II, Napoli 80126, Italy \\ ${ }^{10}$ Dipartimento di Scienze e Tecnologie Biologiche e Ambientali. Università del Salento. Lecce 73100, Italy
}

*Corresponding author: paola.pontieri@ibbr.cnr.it

\begin{abstract}
A white food-grade waxy sorghum Tw variety, grown in two Mediterranean sites (named Tw1M and Tw1S) was evaluated for nutrient composition and fatty acid- and mineral concentrations in order to determine the suitability of producing waxy sorghum for human uses in southern Italy. The nutritional values of the grains of the Tw inbred line grown in the two trial fields were substantially the same, except for slight differences in ash level and accordingly slight variation in mineral composition. In samples from both locations, a higher percentage of $\mathrm{K}$ was observed among the nutritionally essential macro-elements, and higher percentages of $\mathrm{Zn}, \mathrm{Fe}, \mathrm{Mn}, \mathrm{Cu}, \mathrm{Al}$ among the nutritionally essential micro-element along with a strong difference in $\mathrm{Cd}$ content was among trace elements. Across both sites linoleic, oleic and palmitic were the most abundant fatty acids, while very slight variations in the content of minerals were found among the two samples examined. These results demonstrate the importance of developing agronomically productive waxy sorghum varieties suitable for growth in non-traditional sorghum producing regions both as a food and feed crop (i.e. with good nutritional quality) and for utilization in new products at the industrial level.
\end{abstract}

Keywords: chemical composition, fatty acids, Mediterranean area, mineral, waxy sorghum inbred line. Abbreviations: $C D$ _celiac disease; LOA_linoleic acid; OA_oleic acid; PA_palmitic acid; SD_standard deviation.

Introduction

Sorghum [Sorghum bicolor (L.) Moench] is the fifth most important cereal crop in terms of production $(\div 58$ million tonnes in 2011), with Africa being the major producing region ( $>40 \%$ of world production) (FAOSTAT, 2013). Notably, sorghum is highly suited for cultivation in the semiarid and sub-tropical regions of Africa as it is one of the most drought-tolerant cereal crops (Elhassan et al., 2015; Awika and Rooney, 2004; Kresovich et al., 2005; Dendy, 1995; Anglani, 1998; Reddy et al., 2009; Ashok-Kumar et al., 2010; Dicko et al., 2006; Pontieri and Del Giudice, 2016). Recently molecular evidence for the absence of toxic gliadin-like peptides in sorghum has been reported (Pontieri et al., 2013), confirming that sorghum can be definitively considered safe for dietary consumption in people with $C D$ (Ciacci et al., 2007; Pontieri et al., 2013). In addition to being a safe food for people with $C D$, over the past decade the potential role of sorghum in human health and disease prevention in general has gained increased research attention (Anglani, 1998; Awika and Rooney, 2004; Dicko et al., 2006; Taylor et al., 2006; Stefoska-Needham et al., 2015; Pontieri and Del Giudice, 2016; Smolensky et al., 2018).

The United States is the largest producer and exporter of sorghum in the world (Pontieri and Del Giudice, 2016). Sorghum use in human food products has increased and expanded from early efforts in the U.S. developing hybrids that yield white grain from a tan-color plant (often called "food-grade" sorghum) for production of gluten-free foods for people with CD (Tuinstra, 2008). Moreover, new technologies, aimed at enhancing the nutritional and functional values of sorghum proteins in industrial-scale processes, have been developed (de Mesa-Stonestreet et al., 2010; Taylor et al., 2013). As mentioned above, sorghum is 
also receiving increased attention for many other health benefits as well and it provides benefits as a gluten-free food and as a food for all people (Pontieri and Del Giudice, 2016). Public and private breeding programs have released many improved sorghum varieties adapted to semi-arid and tropic environments including cultivars that meet specific food and industrial requirements (Tuinstra, 2008). Sorghum is known for its genetic diversity and many thousands of sorghum accessions and landraces have been collected and developed and are represented in seed collections around the world, particularly collections in Ethiopia, China, USA, and International Crops Research Institute for the Semi-Arid Tropics (ICRISAT) (Rosenow and Dahlberg, 2000).

The genetic diversity of sorghum provides an opportunity to improve the crop at the genetic level. However, with regards to grain composition and grain quality, few of the large numbers of accessions held in seed banks have been characterized for grain composition and increased characterization of grain composition and quality in general has been identified as an important area of research (Bean et al., 2018). Specifically, for food and feed uses of sorghum, there is a need for further characterization of the sorghum collections with respect to food functionality and other quality attributes such as grain nutrient composition and overall nutritional quality of sorghum grain. While needed for sorghum types in general, grain nutritional composition is even more limited in specialty types of sorghum not widely grown such as waxy sorghum. Waxy sorghum grains have been shown to possess a higher nutritive value than non-waxy grains in both feeding (Sarka and Dvoracek, 2017) and digestion trials (Mezgebe et al., 2018). The advantage of waxy sorghum in such areas has been attributed to the type of starch. Waxy sorghum contains $100 \%$ amylopectin, whereas normal (nonwaxy) sorghum contains 75\% amylopectin and 25\% amylose. Sandstedt et al. (1962) indicated that waxy sorghum starch had a greater rate of digestibility than normal sorghum starches. However, the increased nutritional value of waxy sorghum may be due to a combination of greater starch susceptibility and an alteration in the structures of the endosperm of the waxy sorghum kernels (Rooney and Pflugfelder 1986).

With the aim of selecting improved waxy sorghum varieties, determining the nutritional composition of inbred waxy varieties for use in breeding programs is one strategy of improving the beneficial nutritional aspects of waxy sorghum lines, while minimizing the agronomic problems of reduced yield and stand establishment (e.g. Jampala et al., 2012). Thus, the purpose of this research was to evaluate the nutritional properties of a waxy inbred Tw sorghum line grown in two Mediterranean sites of southern Italy, a region that does not typically produce sorghum grain, but that has been shown suitable for sorghum grain production (Pontieri et al., 2010; 2011; 2012; 2014; 2016) and thus may benefit from production of waxy sorghum with improved nutritional attributes.

\section{Results}

\section{Nutrient composition}

The waxy sorghum Tw inbred line (Table 1) was replicated in two separate trial fields, named Tw1M and Tw1S, respectively, and the results of the nutritional values between the two locations were compared. As can be seen in Table 2, the nutritional profiles of the waxy grain coming from the two locations were similar. A slight variation was observed in the ash content was seen, with ash content higher in the grain from Tw1M compared to grain sampled from Tw1S location, probably due to a slight difference in the composition of the soil.

\section{Fatty acid composition of total lipids}

Fatty acid composition of total lipids from the two sorghum samples is presented in Table 3. OA was the predominant fatty acid in all extracts, followed by LOA and PA This result agreed with those previously reported for non-waxy sorghum (Osagie, 1987; Serna-Saldivar and Rooney, 1995; Pontieri et al., 2011). The percentage of both OA and PA was similar in samples from both locations, while the percentage of LOA of the Tw1M sample was higher in comparison with that of the Tw1S sample. The results in Table 3 are also illustrated by bar graph (Fig. 1).

\section{Mineral grain concentrations}

Results of macro-element, micro-element, and trace element analyses of the waxy sorghum grown at both field locations are reported in Fig. 2, in Fig. 3 and in Fig. 4, respectively. The content of macro-elements followed the sequence $\mathrm{K}>\mathrm{Mg}>\mathrm{Ca}>\mathrm{Na}$ in the analyzed samples. Microelements and heavy metals content followed the sequence $\mathrm{Zn}>\mathrm{Fe}>\mathrm{Mn}>\mathrm{Cu}>\mathrm{Al}>\mathrm{Cr}>\mathrm{Ni}>\mathrm{Ba}>\mathrm{Mo}>\mathrm{Pb}>\mathrm{Ag}>\mathrm{As}>\mathrm{Sn}$ $>\mathrm{Co}>\mathrm{Se}>\mathrm{Be}>\mathrm{V}>\mathrm{Tl}$. The content of toxic trace elements followed the sequence $\mathrm{Cd}>\mathrm{Hg}>\mathrm{U}>\mathrm{Sb}$. Slight variations in the content of the elements were found between the two locations, except for $\mathrm{Cd}$ whose content in the waxy sorghum grown at location Tw1S was more than double that of the sample from Tw1M. The most abundant macro-element in samples from both locations was $\mathrm{K}$, with $\mathrm{Zn}$ and $\mathrm{Cd}$ the most abundant micro element and trace element respectively for both field locations. Potassium and sodium contents of both the Tw1M and Tw1S samples varied from 16.30 to $16.12 \mathrm{~g}$ $\mathrm{Kg}^{-1}$ and 0.17 to $0.09 \mathrm{~g} \mathrm{Kg}^{-1}$, respectively. The potassium content of both the samples from Tw1M and Tw1S locations ranged on average about 124-fold higher than that of sodium. Therefore, the K:Na ratio was similar or higher than the recommended ratio 5.0 for the human diet (Szentmihalyi et al., 1998).

\section{Discussion}

There is strong interest in the developing the cultivation of white, tan-plant, food-grade sorghum lines for production in the Mediterranean area (Pontieri et al. 2010, 2011, 2012, $2014,2016)$. Accordingly, research has focused on selecting white food-grade sorghum varieties with improved nutritional characteristics and high yielding capacity. It has long been reported that waxy grains have been shown to possess a higher nutritive value than nonwaxy grains (Sarka and Dvoracek, 2017; Mezgebe et al., 2018). However waxy sorghum grain has not been widely utilized due to yield penalties, though research has suggested it may be possible to overcome these limitations with dedicated breeding efforts (Jampala et al., 2012). Due to the potential for waxy sorghum starch to have unique functional properties (Bean et al., 2019) as well as increased digestibility, the present research work was aimed at evaluating the nutritional 
Table 1. Tw waxy sorghum inbred line used in this study.

\begin{tabular}{lllll}
\hline Entry & Pedigree & Source & Type & Origin \\
\hline Tw & B.T $x$ ARG-1 & WL08-712 & waxy food grade & M. Tuinstra \\
\hline
\end{tabular}

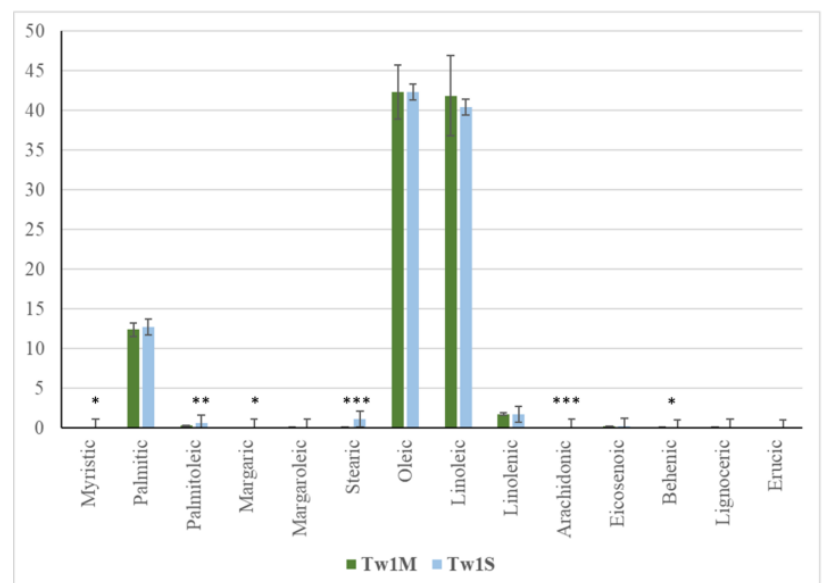

Fig 1. Bar graph of fatty acids contents $(\mathrm{g} / 100 \mathrm{~g}$ raw fat) of the Tw waxy sorghum inbred line grown at Tw1M and Tw1S field locations showing, in particular, the concentrations of OA, LOA and PA. Values are means of four replicates \pm SD (5 replicates). Asterisk $(*)$ indicates $p$-value $<0.05,{ }^{* *}$ indicates $p$-value $>0.01, * * *$ indicates $p$-value $>0.001$.

Table 2. Nutritional values of the Tw waxy sorghum inbred line grown at Tw1M and Tw1S field locations. Asterisk (*) indicates $p$ value<0.05.

\begin{tabular}{|c|c|c|c|c|}
\hline & ${ }^{\mathrm{a}} \mathrm{Tw} 1 \mathrm{M}$ & ${ }^{\mathrm{b}} \mathrm{Tw} 1 \mathrm{~S}$ & Tw1M & Tw1S \\
\hline & $\%$ & $\%$ & ${\mathrm{~g} 100 \mathrm{~g}^{-1} \text { raw fat }}$ & ${\mathrm{g} 100 \mathrm{~g}^{-1} \text { raw fat }}$ \\
\hline Moisture & $11.5 \pm 0.8$ & $11.8 \pm 0.8$ & & \\
\hline Ash & $2.0 \pm 0.1$ & $1.7 \pm 0.1 *$ & & \\
\hline Total proteins & $12.1 \pm 1.5$ & $11.8 \pm 0.8$ & & \\
\hline Total fats & $2.79 \pm 0.17$ & $2.53 \pm 0.20$ & & \\
\hline Total carbohydrates & $71.61 \pm 6.44$ & $71.65 \pm 6.45$ & & \\
\hline Sugars & $1.5 \pm 0.2$ & $1.3 \pm 0.1$ & & \\
\hline Fiber & $2.90 \pm 0.35$ & $2.62 \pm 0.21$ & & \\
\hline Saturated fats & & & $0.35 \pm 0.02$ & $0.36 \pm 0.04$ \\
\hline Monounsaturated fats & & & $1.19 \pm 0.12$ & $1.09 \pm 0.10$ \\
\hline Polyunsaturated fats & & & $1.25 \pm 0.09$ & $1.08 \pm 0.10$ \\
\hline
\end{tabular}

${ }^{\mathrm{a}} \mathrm{Tw} 1 \mathrm{M}$ and ${ }^{\mathrm{b}} \mathrm{Tw} 1 \mathrm{~S}$ represent the two sites in which the Tw waxy sorghum inbred line was cultivated.

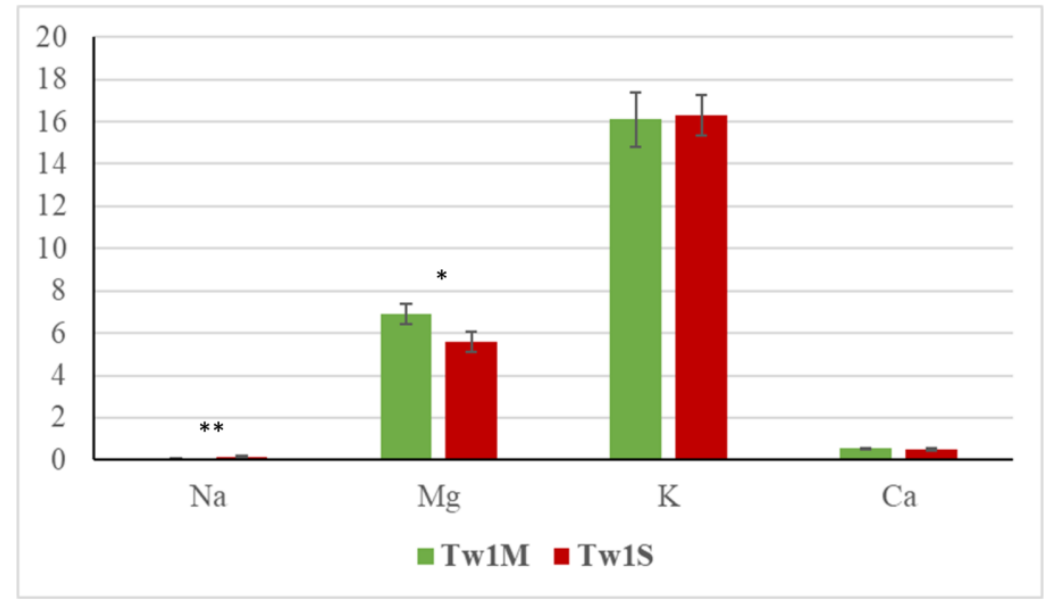

Fig 2. Bar graph of nutritionally essential macro-elements content $\left(\mathrm{g} \mathrm{Kg}^{-1}\right)$ of the Tw waxy sorghum inbred line showing the concentrations of macro-elements $\mathrm{Na}, \mathrm{Mg}, \mathrm{K}$ and $\mathrm{Ca}$. The content of each macro-element followed the sequence $\mathrm{K}>\mathrm{Mg}>\mathrm{Ca}>\mathrm{Na}$ in the waxy line grown at both Tw1M and Tw1S field locations. Values are means of four replicates \pm SD (5 replicates). Asterisk ( $\left.{ }^{*}\right)$ indicates $p$-value $<0.05,{ }^{* *}$ indicates $p$-value $>0.01$. 
Table 3. Fatty acid content ( $\mathrm{g} / 100 \mathrm{~g}$ raw fat) of the waxy sorghum Tw inbred line grown at Tw1M and Tw1S field locations. Asterisk $(*)$ indicates $p$-value $<0.05, * *$ indicates $p$-value $>0.01, * * *$ indicates $p$-value $>0.001$.

\begin{tabular}{|c|c|c|}
\hline & ${ }^{\mathrm{a}} \mathrm{Tw1M}$ & ${ }^{\mathrm{b}} \mathrm{Tw1S}$ \\
\hline Myristic & $0.055 \pm 0.004$ & $0.070 \pm 0.006^{*}$ \\
\hline Palmitic & $12.380 \pm 0.867$ & $12.680 \pm 1.522$ \\
\hline Palmitoleic & $0.320 \pm 0.035$ & $0.580 \pm 0.070 * *$ \\
\hline Margaric & $0.026 \pm 0.02$ & $0.07 \pm 0.006 *$ \\
\hline Margaroleic & $0.040 \pm 0.03$ & $0.07 \pm 0.006$ \\
\hline Stearic & $0.063 \pm 0.05$ & $1.110 \pm 0.089 * * *$ \\
\hline Oleic & $42.320 \pm 3.386$ & $42.330 \pm 3.810$ \\
\hline Linoleic & $41.850 \pm 5.022$ & $40.450 \pm 4.854$ \\
\hline Linolenic & $1.760 \pm 0.176$ & $1.670 \pm 0.117$ \\
\hline Arachidonic & $0.024 \pm 0.02$ & $0.160 \pm 0.014 * * *$ \\
\hline Eicosanoic & $0.220 \pm 0.026$ & $0.230 \pm 0.023$ \\
\hline Behenic & $0.076 \pm 0.08$ & $0.000 \pm 0.000 *$ \\
\hline Lignoceric & $0.054 \pm 0.06$ & $0.064 \pm 0.007$ \\
\hline Erucic & $0.001 \pm 0.000$ & $0.006 \pm 0.000$ \\
\hline
\end{tabular}

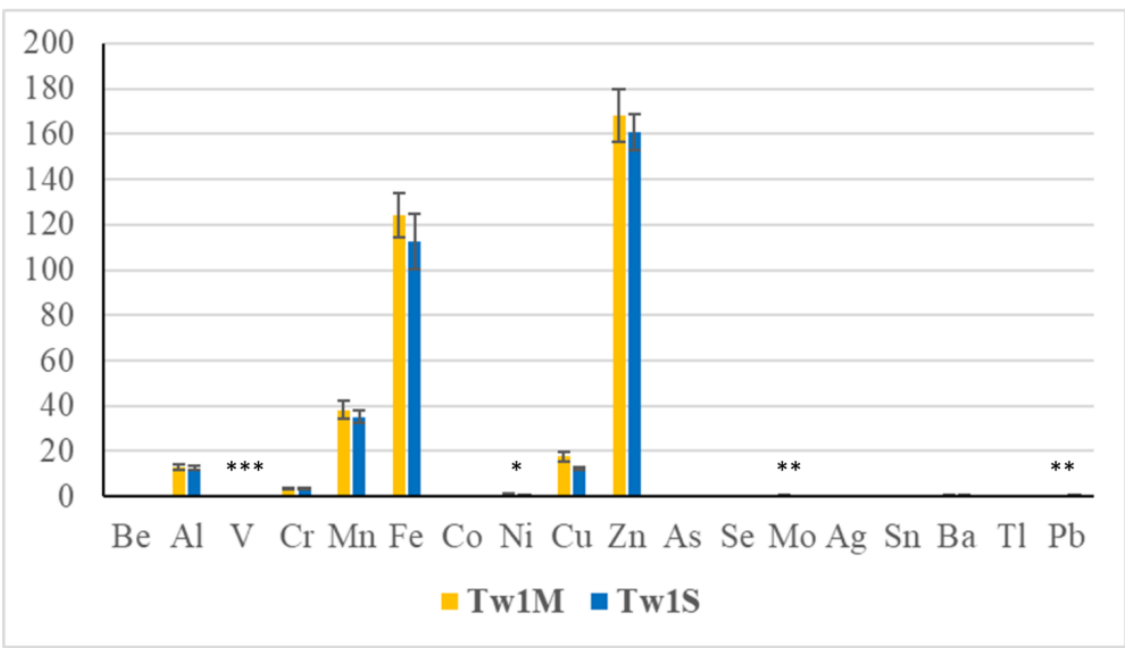

Fig 3. Bar graph of nutritionally essential micro-elements content $\left(\mathrm{mg} \mathrm{Kg}^{-1}\right)$ of the Tw waxy sorghum inbred line showing the concentrations of micro-elements $\mathrm{Zn}, \mathrm{Fe}, \mathrm{Mn}, \mathrm{Cu}, \mathrm{Al}$. The content of each microelement followed the sequence $\mathrm{Zn}>\mathrm{Fe}>\mathrm{Mn}>\mathrm{Cu}>$ $\mathrm{Al}$ in the waxy line grown at both Tw1M and Tw1S locations. Values are means of four replicates \pm SD (5 replicates). Asterisk $(*)$ indicates $p$-value $<0.05, * *$ indicates $p$-value $>0.01, * * *$ indicates $p$-value $>0.001$.

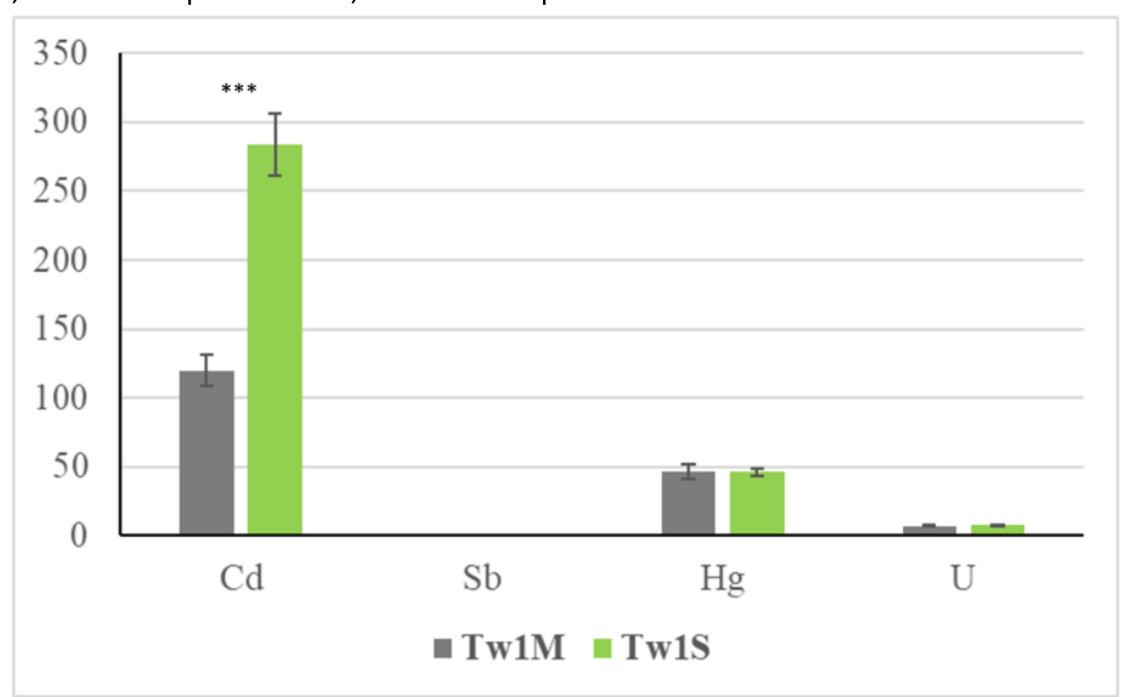

Fig 4. Bar graph of toxic trace elements content $\left(\mu \mathrm{g} \mathrm{Kg}^{-1}\right)$ of the Tw waxy sorghum inbred line showing the concentrations of trace elements $\mathrm{Cd}, \mathrm{Sb}, \mathrm{Hg}$, and $\mathrm{U}$. The content of each microelement followed the sequence $\mathrm{Cd}>\mathrm{Hg}>\mathrm{U}>\mathrm{Sb}$ in the waxy line grown at both Tw1M and Tw1S field sites. Values are means of four replicates \pm SD ( 5 replicates). Asterisks $* * *$ indicates $p$-value $>0.001$. 
properties of a waxy sorghum variety developed in the USA and grown in the Mediterranean environment of southern Italy at two field locations as it is well known that sorghum grain composition varies significantly due to genetics and environment (Serna-Saldivar and Rooney, 1995; Bean et al.2018).

The inbred Tw line of white food-grade sorghum (Table 1) was grown in 2018 in southern Italy in two separate field trials named Tw1M and Tw1S, respectively. As shown in Table 2, the chemical composition of the waxy sorghum grown at both Tw1M and Tw1S were comparable. A slight difference was observed in both the ash content and fiber levels with the sample grown at Tw1M having higher levels of both than the sample grown at Tw1S. That difference could be due to a slight disparity in soil composition as the cultivation of the Tw sorghum variety was carried out in two separate locations where the clay loam soil composition is known to be slightly different (Pontieri et al., 2016).

As shown in both Table 3 and Fig. 1, OA was the predominant fatty acid in both field trials, followed by LOA and PA, which was consistent with previous results (Osagie, 1987; Serna-Saldivar and Rooney, 1995; Pontieri et al, 2011). The fatty acid composition for samples from both Tw1M and Tw1S locations was qualitatively and quantitatively similar with only very slight variations. Furthermore, it should be emphasized that the levels of protein, fat, fiber and LOA in the waxy line grown at both Tw1M and Tw1S locations were higher than those of the Macia nonwaxy variety previously cultivated in southern Italy (Pontieri et al., 2011).

From these data, it was noted that the monounsaturated fatty acid level in the Tw waxy sorghum line was about $42.30 \%$ on average between the Tw1M and Tw1S locations and was essentially composed of OA. The polyunsaturated fat content was about $41.15 \%$ on average between the Tw1M and Tw1S locations and composed primarily of LOA. Unsaturated fatty acids are of great importance to the human diet, as they are significant components of biological membranes and play a key role as fluidity modulators (Avato et al., 1990). Moreover, unsaturated fatty acids are not cholesterogenic (unlike saturated fatty acids), and lower the risk of thrombosis, due to their anti-aggregating activity on blood lipoprotein particles (Del Giudice and Pontieri, 2017). These two features make intake of unsaturated fatty acids strongly recommended to reduce the risk of atherosclerosis (Dicko et al., 2006; Stefoska-Needham et al., 2015).

For the concentrations of macro-elements, Fig. 2 shows that they followed the sequence $\mathrm{K}>\mathrm{Mg}>\mathrm{Ca}>\mathrm{Na}$ in the waxy line grown at both Tw1M and Tw1S field locations. The most abundant mineral was $\mathrm{K}$, followed by $\mathrm{Mg}$, consistently with literature data (Afify et al., 2012; Pontieri et al., 2014). As for the micro-elements, the content followed the sequence of $\mathrm{Zn}>\mathrm{Fe}>\mathrm{Mn}>\mathrm{Cu}>\mathrm{Al}>\mathrm{Cr}>\mathrm{Ni}>\mathrm{Ba}>\mathrm{Mo}>\mathrm{Pb}>\mathrm{Ag}>\mathrm{As}>$ $\mathrm{Sn}>\mathrm{Co}>\mathrm{Se}>\mathrm{Be}>\mathrm{V}>\mathrm{Tl}$ again across both Tw1M and Tw1S locations (Fig. 3). The most abundant micro-element was $\mathrm{Zn}$, which was different from that of previous findings (Jambunathan, 1980; Afify et al, 2012; Pontieri et al, 2014).

Finally, for trace element, the sequence was $\mathrm{Cd}>\mathrm{Hg}>\mathrm{U}>\mathrm{Sb}$ in the sample from both Tw1M and Tw1S locations

With regards to macro-element content, the present study showed a K:Na ratio higher than the recommended ratio for the human diet in the waxy sample at both Tw1M and Tw1S locations (Szentmihalyi et al., 1998). In fact, it is well known that an improved $\mathrm{K}: \mathrm{Na}$ ratio in the diet may benefit bone health, reduce muscle loss, as well as mitigate other chronic diseases such as hypertension and stroke (Arbeit et al.,
1992). Moreover, the magnesium content in the waxy sorghum from both Tw1M and Tw1S locations was higher than those reported for corn flour (on average, $0.47 \mathrm{~g} \mathrm{Kg}^{-1}$ ) and wheat flour (on average, $0.25 \mathrm{~g} \mathrm{Kg}^{-1}$ ) as reported in Danish Food Composition Databank (Saxholt et al., 2008). Since the samples grown at both Tw1M and Tw1S locations have higher magnesium contents, they could be considered as sources of magnesium, which is required for the function of many enzyme systems in human metabolism (Saxholt et al., 2008).

Regarding micro-element content, the results reported in the present study show high content of both $\mathrm{Zn}$ and $\mathrm{Fe}$ in the waxy sample from both Tw1M and Tw1S field sites. The latter two elements are essential micro-elements in human nutrition, and their deficiencies are major public health threats worldwide (Ashok-Kumar et al., 2010). With reference to the $\mathrm{Cd}, \mathrm{Hg}, \mathrm{U}$, Sb levels, these trace elements could be toxic to human health at concentrations higher than critical limits. However, the concentrations of trace elements in the waxy sorghum Tw from both Tw1M and Tw1S sites analyzed in this study did not exceed the maximum permitted by Regulation (CE) n. 1881/2006.

Sorghum is a major source of calories and protein for over half a billion people in the semiarid countries (Duressa et al., 2018). Sorghum is suited for cultivation on marginal lands in hot and dry areas where other major cereal crops such as maize, wheat, and rice do not thrive. In sub-Saharan Africa and Southeast Asia, sorghum is grown primarily as a food crop by small-scale subsistence farmers in some of the world's most fragile agroecosystems. In other parts of the world, sorghum is principally grown as animal feed, although there is a growing interest in recent years to use sorghum in food, fuel and industrial products (Wang et al., 2017; Duressa et al., 2018, Mezgebe et al., 2018).

Past research has shown that the waxy sorghum grains possess a higher nutritive value than nonwaxy grains in both feeding trials (Sarka and Dvoracek, 2017) and digestion trials (Mezgebe et al., 2018). Improving the functionality of sorghum protein and starch in waxy sorghum hybrids with regards to food production and quality (both technical and nutritional) would also be of benefit, especially for areas of the world that rely on these crops as basic food staples (Bean et al., 2019). The present study evaluated the nutritional quality and composition of grain from an inbred waxy sorghum variety grown in the Mediterranean region of southern Italy with the aim of selecting the best white sorghum waxy varieties for both nutrient content and high yield capacity. The results also build on previous works (Pontieri et al., 2010, 2011, 2012, 2014, 2016) on the possibility of expanding sorghum cultivation in the Mediterranean for human use and demonstrate the possibility of producing waxy sorghum grain with good nutrient composition as an alternative or compliment to non-waxy sorghum in this region of the world.

\section{Materials and Methods}

\section{Sorghum cultivars}

The white food-grade waxy sorghum Tw variety and seed source employed in this study is described in Table 1. Full field cultivation was carried out in two separate sites of San Bartolomeo in Galdo (BN), southern Italy $\left(41^{\circ} 25^{\prime} \mathrm{N}, 15^{\circ} 01^{\prime} \mathrm{E}\right.$ and $597 \mathrm{~m}$ a.s.I.), where soils are predominantly clay loam, deep and with good water holding capacity during 2018. 


\section{Flour sample preparation}

Approximately $1000 \mathrm{~g}$ of grain samples for each replication were milled into flour with a two-roll mill (Chopin mod. Moulin CD1). Subsequently, these flours were passed through a planetary sieve (Buhler), with a $120 \mu \mathrm{m}^{2}$ sieve opening.

\section{Moisture content}

Flour moisture was determined according to the AOAC method 925.09 (AOAC, 1995) as described by Pontieri et al. (2011).

\section{Ash}

For ash measurement, sorghum samples ( 3g each) were weighed into an ashing dish that was ignited at $\sim 550^{\circ} \mathrm{C}$, cooled in a desiccator, and weighed soon after reaching room temperature (AOAC, 1923).

\section{Protein content}

Nitrogen concentration was obtained by the Kjeldahl method 920.87 (AOAC, 1920), and total protein content was estimated using a conversion factor of 6.25. Sorghum samples (2 $\mathrm{g}$ each) were analyzed using a Mineral Six Digester and an Auto Disteam semi-automatic distillation unit (International PBI, Milan, Italy).

\section{Total lipid content}

Lipid content in the grain samples was determined as described by Pontieri et al. (2010). About $3 \mathrm{~g}$ each sample was ground with liquid nitrogen in a mortar and lyophilized using an FTS-System Flex-Dry ${ }^{\mathrm{TM}}$ instrument (FTS Systems, Stone Ridge, NY). The samples were extracted using a Soxhlet apparatus with chloroform $\left(\mathrm{CHCl}_{3}\right)$ for $4 \mathrm{hrs}$, then dried using a rotary evaporator to obtain the crude extracts which were weighed to obtain the amount of extracted fat.

\section{Gas Chromatography of fatty acids}

Esterification of fatty acids and subsequent analysis using gas chromatography was carried out as described by Pontieri et al. (2011).

\section{Carbohydrates}

Total carbohydrates were determined by ion chromatography as described by Arienzo et al. (2003).

\section{Fiber}

Fiber was determined according to the AOAC method 962.09 (AOAC, 1995). Specifically, fiber was considered to be the loss, after incineration, of the sample digested in acid $(0.255$ $\mathrm{N} \mathrm{H}_{2} \mathrm{SO}_{4}$ ), followed by an alkaline digestion in $0.223 \mathrm{~N} \mathrm{NaOH}$. Digestion was obtained with an automatic digester (Velp Scientific mod. FIWE3).

\section{Total minerals determination}

The determination of the mineral elements of interest was performed according to Tenore et al. (2012) as described by Pontieri et al. (2014).

\section{Statistical analysis}

All analyses were performed in quintupled $(n=5)$, and the results are presented as mean \pm SD. Data distribution were evaluated by means of Shapiro-Wilks test. Since not all the data resulted in normal distribution, differences in means were investigated using the non-parametric $U$ test of MannWhitney. No significant $\mathrm{G} \times \mathrm{E}$ interaction was observed.

\section{Conflict of Interest}

The authors declare that there is no conflict of interest.

\section{Acknowledgements}

We thank Prof. Mitchell Tuinstra for a generous gift of the food-grade sorghum waxy inbred Tw variety. The technical assistance of both Concetta Porzio and Federico Gomez Paloma is acknowledged. Names are necessary to report factually on available data; however, the U.S. Department of Agriculture neither guarantees nor warrants the standard of the product and use of the name by the U.S. Department of Agriculture implies no approval of the product to the exclusion of others that may also be suitable.

\section{Funding informations}

The research was supported by MIUR- PONO3PE_00060_2, Decreto di Concessione del 27/06/2014, Progetto 2 "Progettazione, sviluppo e produzione di cibi funzionali e/o arricchiti", (OR4: Farine funzionali e prodotti da forno per celiaci ed intolleranti al glutine) to P. Pontieri and by CNRDISBA project NutrAge (project nr. 7022).

\section{References}

Afify AMR, El-Beltagi HS, El-Salam SM, Omran AA (2012) Effect of soaking, cooking, germination and fermentation processing on proximate analysis and mineral content of three white sorghum varieties (Sorghum bicolor L. Moench). Not Bot Horti Agrobo. 40(2):92-98.

Anglani C (1998) Sorghum for human food: a review. Plant Food Hum Nutr. 52:85-89.

AOAC (1920) Association of Analytical Chemists Official Method, 920.87. Protein (total) in flour.

AOAC (1923) Association of Analytical Chemists Official Method, 923.03. Ash of flour, direct method. J AOAC Inter. 7:132.

AOAC (1995) Association of Analytical Chemists Official Method, 962.09. Fiber (crude) in animal feed and pet food. In: Cunniff P (ed.) Offic. Meth. Anal. AOAC Intern., 16 th edn.

Arbeit ML, Nicklas TA, Berenson GS (1992) Considerations of dietary sodium/potassium/energy ratios of selected foods. J Am Coll Nutr. 11(2):210-222. 
Arienzo M, De Martino A, Capasso R, Di Maro A, Parente A (2003) Analysis of carbohydrates and amino acids in vegetable waste waters by ion chromatography. Phytochem Anal. 14:74-82.

Ashok-Kumar A, Reddy BVS, Sahrawat KL, Ramaiah B (2010) Combating micronutrient malnutrition: identification of commercial sorghum cultivars with high grain iron and zinc. J SAT Agric Res. 8:1-5.

Avato P, Bianchi G, Murelli C (1990) Aliphatic and cyclic lipid components of sorghum plant organs. Phytochemistry. 29:1073-1078.

Awika JM, Rooney LW (2004) Sorghum phytochemicals and their potential aspects on human health. Phytochemistry. 65:1199-1221.

Bean SR, loerger BP, Wilson JD, Tilley M, Rhodes, DH, and Herald, TJ (2018) Structure and chemistry of sorghum grain. In: Rooney W (ed), Achieving sustainable cultivation of sorghum. Burleigh Dodds.

Bean SR, Zhu L, Smith BM, Wilson JD, loerger BP, Tilley M (2019) Starch and protein

chemistry and functional properties. In: Taylor JRN, Duodu K (eds.) Sorghum and millets: chemistry and technology, 2 nd edn. Elsevier, San Diego, CA.

Ciacci C, Maiuri L, Caporaso N, Bucci C, Del Giudice L, Massardo DR, Pontieri P, Di Fonzo N, Bean SR, loerger B, Londei M (2007) Celiac disease: in vitro and in vivo safety and palatability of wheat-free sorghum food products. Clin Nutr. 26:799-805.

de Mesa-Stonestreet NJ, Alavi S, Bean SR (2010) Sorghum proteins: the concentration, isolation, modification, and food applications of kafirins. J Food Sci. 75(5):R90-R104.

Del Giudice L, Pontieri P (2017) Sorghum grain as human healthy nutritious cereal. Verlag/Publisher: Lap Lambert Academic Publishing, Germany.

Dendy DAV (1995) Sorghum and the millets: production and importance. In: Dendy DAV (ed) Sorghum and millets: chemistry and technology. American Association of Cereal Chemists, St. Paul, MN.

Dicko MH, Gruppen H, Traoré AS, Voragen AGJ, van Barkel WJH (2006) Sorghum grain as human food in Africa: relevance of content of starch and amylase activities. Afr J Biotechno. 5(5):384-395

Duressa D, Weerasoriya D, Bean SR, Tilley M, Tesso T (2018) Genetic basis of protein digestibility in grain sorghum. Crop Sci. 58: 2183-2199.

Elhassan MSM, Emmambux MN, Hays DB, Peterson GC, Taylor JRN (2015) Novel biofortified sorghum lines with combined waxy (high amylopectin) starch and high protein digestibility traits: effects on endosperm and flour properties. J Cereal Sci. 65:132-139.

FAOSTAT -Food and Agriculture Organization of the United Nations (2013) Crops. <http://faostat.fao.org/site. November 2014>.

Jambunathan R (1980) Improvement of the nutritional quality of sorghum and pearl millet. Food Nutr Bull. 2:1116.

Jampala B, Rooney WL, Peterson GC, Bean S, Hays DB (2012) Estimating the relative effects of the endosperm traits of waxy and high protein digestibility on yield in grain sorghum. Field Crops Res. 139: 57-62.

Kresovich S, Barbazuk B, Bedell JA (2005) Toward sequencing the sorghum genome. A U.S. national science foundationsponsored work report. Plant Physiol. 138(4):1898-1902.
Mezgebe AG, Abegaz K, Taylor JRN (2018) Relationship between waxy (high amylopectin) and high protein digestibility traits in sorghum and malting quality. J Cereal Sci. 79:319-327.

Osagie AU (1987) Total lipids of sorghum grain. J Agric Food Chem. 35:601-604.

Pontieri P, Di Maro A, Tamburino R, De Stefano M, Tilley M, Bean SR, Roemer E, De Vita P, Alifano P, Del Giudice L, Massardo DR (2010) Chemical composition of selected food-grade sorghum varieties grown under typical mediterranean conditions. Maydica. 55:139-143.

Pontieri P, Di Fiore R, Troisi J, Bean SR, Roemer E, Okot J, Alifano P, Pignone D, Del Giudice L, Massardo DR (2011) Chemical composition and fatty acid content of white food sorghums grown in different environments. Maydica. 56(1):51-57.

Pontieri P, De Vita P, Boffa A, Tuinstra MR, Bean SR, Krishnamoorthy G, Miller C, Roemer E, Alifano P, Pignone D, Massardo DR, Del Giudice L (2012) Yield and morphoagronomical evaluation of food-grade white sorghum hybrids grown in southern Italy. J Plant Interact. 7(4):341347.

Pontieri P, Mamone G, De Caro S, Tuinstra MR, Roemer E, Okot J, De Vita P, Ficco DB, Alifano P, Pignone D, Massardo DR, Del Giudice L (2013) Sorghum, a healthy and glutenfree food for celiac patients as demonstrated by genome, biochemical and immunochemical analyses. J Agric Food Chem. 61:2565-2571.

Pontieri P, Troisi J, Di Fiore R, Di Maro A, Bean SR, Tuinstra MR, Roemer E, Boffa A, Del Giudice A, Pizzolante G, Alifano $P$, Del Giudice $L$ (2014) Mineral content in grains of seven food-grade sorghum hybrids grown in a Mediterranean environment. Aust J Crop Sci. 8:1550-1559.

Pontieri P, Del Giudice L (2016) Sorghum: a novel and healthy food, In: Caballero B, Finglas P, Toldrà F (eds) The encyclopedia of food and health. Academic Press, Oxford, UK.

Pontieri P, Del Giudice F, Dimitrov MD, Pesheva MG, Venkov PV, Di Maro A, Pacifico S, Gadgil P, Herald TJ, Tuinstra MR, Pizzolante G, Romano R, Alifano P, Del Giudice L (2016) Measurement of biological antioxidant activity of seven food-grade sorghum hybrids grown in a Mediterranean environment. Aust J Crop Sci. 10(7):904-910.

Reddy BVS, Ramesh S, Sanjana-Reddy P, Ashok-Kumar A (2009) Genetic enhancement for drought tolerance in sorghum. Plant Breed Rev. 31:189-222.

Rooney LW, Pflugfelder RL (1986) Factors affecting starch digestibility with special emphasis on sorghum and corn. J Animal Sci. 63(5):1607-1623.

Rosenow DT, Dahlberg JA (2000) Collection, conversion, and utilization of sorghum. In: Smith CW, Frederiksen RA (eds) Sorghum: origin, history, technology, and production. Wiley, New York

Sandstedt RM, Strahan D, Ueda S, Abbott RC (1962) The digestibility of high amylose corn starches. The apparent effect of the ae gene on susceptibility to amylase action. Cereal Chem. 39:123-131.

Sarka E, Dvoracek V (2017) New processing and applications of waxy starch (a review). J Food Eng. 206:77-87.

Saxholt E, Christensen AT, Møller A, Hartkopp HB, Hess-Ygil K, Hels OH (2008) Danish food composition databank, revision 7. Department of Nutrition, National Food Institute, Technical University of Denmark. 
Serna-Saldivar SO, Rooney LW (1995) Structure and chemistry of sorghum and millets. In: Dendy DAV (ed), Sorghum and millets: chemistry and technology. American Association of Cereal Chemists, St. Paul, MN.

Smolensky D, Rhodes D, McVey DS, Fawver Z, Perumal R, Herald T, Noronha L (2018) High-polyphenol sorghum bran extract inhibits cancer cell growth through ROS induction, cell cycle arrest, and apoptosis. J Med Food. 21(10):990998.

Stefoska-Needham A, Beck EJ, Johnson SK, Tapsell LC (2015) Sorghum: an underutilized cereal whole grain with the potential to assist in the prevention of chronic disease. Food Rev Int. 31:401-437.

Szentmihalyi K, Kéry A, Then M, Lakatos B, Sándor Z, Vinkler $P$ (1998) Potassium-sodium ratio for the characterisation of medicinal plant extracts with diuretic activity. Phytother Res. 12(3):163-166.
Taylor JRN, Schober TJ, Bean SR (2006) Novel food and nonfood uses for sorghum and millets. J Cereal Sci. 44:252271.

Taylor J, Anyango JO, Taylor JRN (2013) Developments in the science of zein, kafirin, and gluten protein bioplastic materials. Cereal Chem. 90:344-357.

Tenore GC, Troisi J, Di Fiore R, Basile A, Novellino E (2012) Chemical composition, antioxidant and antimicrobial properties of rapa catozza napoletana (Brassica rapa L. var. rapa DC.) seed meal, a promising protein source of Campania region (southern Italy) horticultural germplasm. J Sci Food Agric. 92:1716-1724.

Tuinstra MR (2008) Food-grade sorghum varieties and production considerations: a review. J Plant Interact. 3(1):69-72.

Wang C, Zhou L, Zhang G, Xu Y, Zhang L, Gao X, Gao J, Jiang N, Shao M (2017) Optimal fertilization for high yield and good quality of waxy sorghum (Sorghum bicolor L. Moench). Field Crops Res. 203:1-7. 